
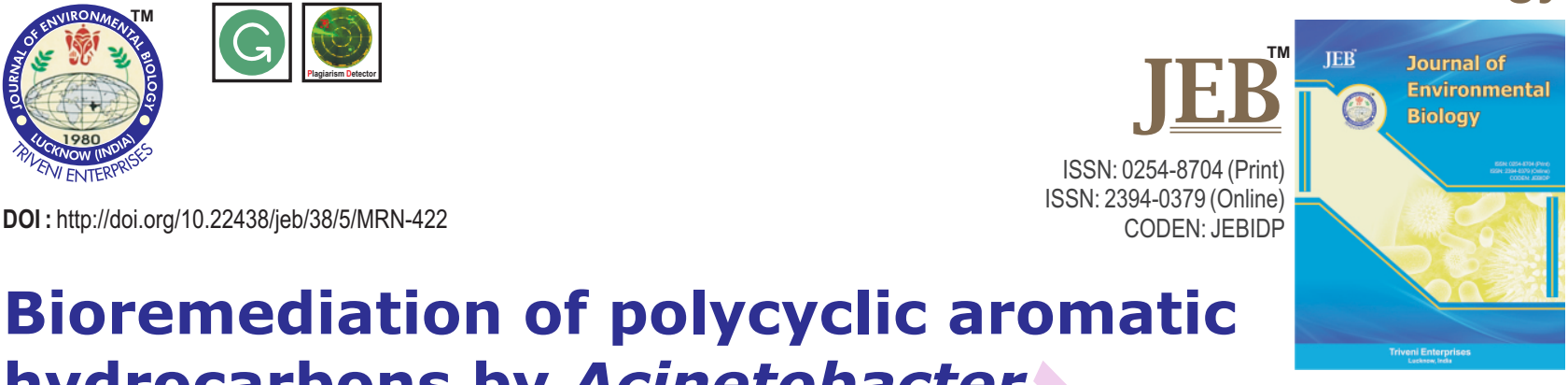

\title{
Bioremediation of polycyclic aromatic hydrocarbons by Acinetobacter species isolated from ecological sources
}

\section{Authors Info}

\section{H.T. Al-Hadithi', E.A. Al-Razzaq ${ }^{2}$} and G.F. Fadhil ${ }^{3 *}$

'Department of Basic

Pharmaceutical Sciences, University of Isra, College of Pharmacy, Amman, 11622, Jordan

${ }^{2}$ Department of Biology, College of Science, University of Basrah, Basrah, 61009, Iraq

${ }^{3}$ Department of Chemistry, College of Science, University of Duhok,

Duhok, 1048BD, Iraq

${ }^{*}$ Corresponding Author Email : ghazwan.fadhil@uod.ac

Key words

Acinetobacter species Bioremediation,

Polycyclic aromatic hydrocarbons

Publication Info

Paper received : 20.07.2016

Revised received : 21.12.2016

Re-revised received : 01.03.2017

Accepted: 09.03.2017

\section{Abstract}

Aim: The objective of the present study was to isolate Acinetobacter from ecological sources in Basrah city, the Iraq's main port located on the Shatt al-Arab, to identify recovered species and to investigate their capability for bioremediation and degradation of Polycyclic aromatic hydrocarbons (PAH).

Methodology: One hundred and five samples were collected from Municipal drinking water, soil and surface water of Shat Al-Arab waterway area / Basrah / Iraq, polluted with diesel oil. Two species of Acinetobacter were isolated and identified according to diagnostic tests. Bioremediation of PAHs was investigated by incubating $5 \times 10^{8}$ bacterial cell $\mathrm{ml}^{-1}$ of either two species in a mineral medium and examined after two weeks, one month and two months adopting gravimetric and spectrophotometric methods. The bacterial density of each species was determined after each incubation period.

Results: Ten Acinetobacter isolates were obtained in a frequency distribution of $9.2523 \%$. Isolates were isolated from three sources and identified as A. Iwoffii (8\%), however, A. calocoacetcus (2\%) was isolated from soil only. Starting with $5 \times 10^{8}$ bacterial cell $\mathrm{ml}^{-1}$ of $A$. calocoacetcus; the count was increased to $8.05 \times 10^{11}$ cell $\mathrm{ml}^{-1}$ after two weeks then decreased to $6.3 \times 10^{5} \mathrm{cell} \mathrm{m}^{-1}$ after one month and became $0.2 \times 10^{2}$ bacterial cell $\mathrm{ml}^{-1}$ after two months. Accordingly, the weight of PAHs decreased from $0.1 \mathrm{~g}$ to $0.053,0.013$ then to $0.001 \mathrm{~g}^{2} 50 \mathrm{ml}^{-1}$ respectively. The same sequence of events was demonstrated by A. Iwoffii, though with a higher rate of degradation confirming its higher potency for bioremediation.

Interpretation: Owing to bioremediation, the weight of $\mathrm{PAH}$ decreased with a concomitant decrease in the growth and activity of either species of Acinetobacter. Hence, it is a promising alternative for cleaning oil spills and reducing the concentration and toxicity of pollutants.

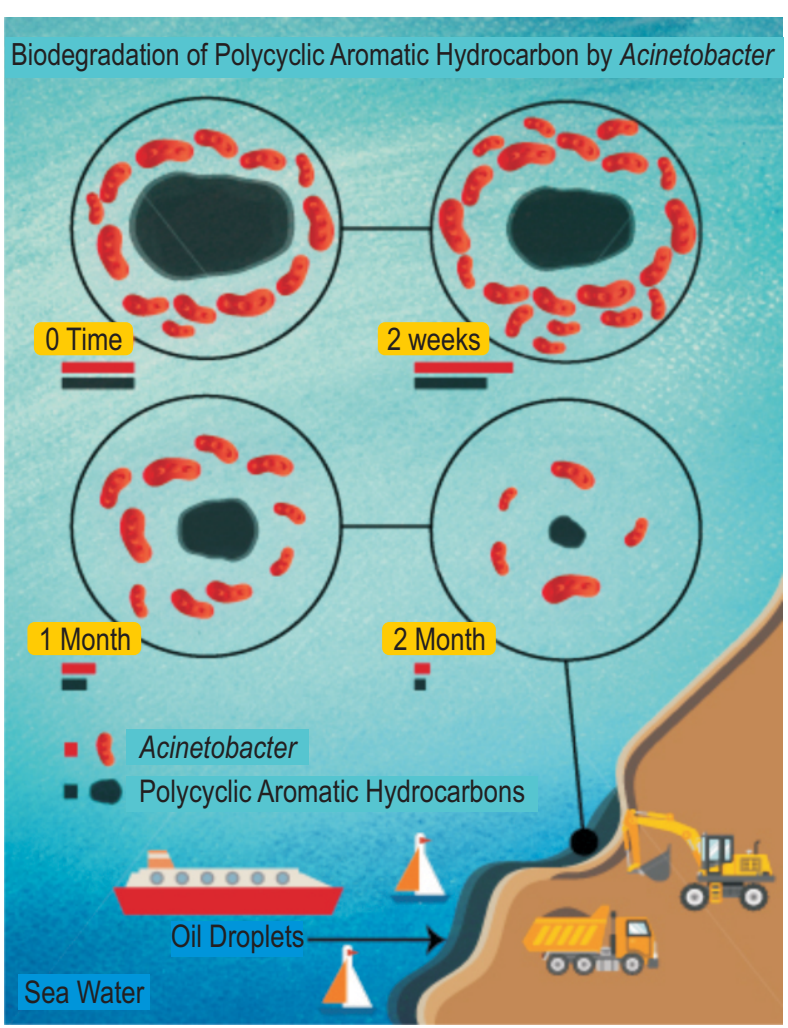




\section{Introduction}

One of the major environmental problems today is hydrocarbon contamination resulting from the activities related to petrochemical industry, ships and small boat navigation in waterways and seas, discarding their engine wastes in water. Also accidental release of petroleum products due to oil production, transportation, and disposal which inevitably generate large quantities of fatty and viscous residue called oily sludge (Skupinska et al., 2004). Polycyclic aromatic hydrocarbons (PAH) are major constituents of oil, coal, and tar deposits which are produced as byproducts of fuel burning. PAH are the diverse class of organic compounds formed by two or more aromatic rings in several structural configurations and have carcinogenic, mutagenic, teratogenic, neurotoxic and toxic properties which adversely affecting human health (Kingston, 2002; Skupinska et al., 2004; Brooijmans, 2009; ATSDR, 2012). It has been shown that bioremediation is the most efficient means to restore original ecosystem conditions (Haritash and Kaushik, 2009; Adams et al., 2015). Several researchers (MacNaughton et al., 1999; Barathi and Vasudevan 2001; Dubinsky et al., 2013; Mason et al., 2014) have revealed that microorganisms play a significant role in insitu biodegradation of hydrocarbons in environment and significance of indigenous oil-degrading bacteria. Bacteria breaks down contaminants by using them as energy source or co-metabolizing them with energy source (Taketani et al., 2010). Two species of bacteria consortium isolated from petrochemical soil and identified as Bacillus cereus and Bacillus vireti (Mohandass et al., 2012). They were found capable of degrading benzo(a)pyrene.

More specifically, bioremediation involves production of energy in a redox reaction within microbial cells (Adams et al., 2015). Fifty-six hydrocarbon utilizing bacterial isolates including Staphylococcus sp and the capacity of Pseudomonas, Actinobacterium, Bacillus and Ralstonia to degrade PAH has long been reported (McMahon et al., 2007). Pseudomonas spp., Citrobacter spp., Klebsiella spp., Micrococcus spp., Corynebacterium spp., Bacillus spp. Rhodococcus spp., Alcanivorax spp., Alcaligenes spp., Serratia spp., Arthrobacter spp., Nocardia spp., Flavobacterium spp., Escherichia sp., Acinetobacter spp. and Proteus spp. were identified from contaminated soil used as a nutrient source for ex situ remediation studies (Das and Chandran, 2011; Chikere, 2012). Fatajeva et al. (2014) recently reported that Acinetobacter had high potential to degrade crude oil and fuel in saline water. The highest degredation of oil was found at $30^{\circ} \mathrm{C}, \mathrm{pH} 7-8$ in model ocean water of $35 \%$ salinity. Since there is a limited number of investigations on the bioremediation technique to clean oil spills in tropical countries, the present study was carried out to isolate Acinetobacter from ecological sources like Municipal drinking water, surface water from Shatt Al- Arab/Basra/lraq and soils contaminated with diesel oil from near storage tanks, petrol stations or garages in Basrah city, Iraq, to identify the recovered species and to investigate their potential for bioremediation and degradation of polycyclic aromatic hydrocarbons (PAH).

\section{Materials and Methods}

Sampling and sample processing: One hundred and five samples were collected as following: Municipal drinking water $(\mathrm{N}=20)$, Surface water from Shatt AL-Arab / Basrah / Iraq from motorized boat area polluted with diesel oil $(\mathrm{N}=35)$ and soils contaminated with diesel oil from areas near storage tanks, petrol stations, or garages and from Shat Al-Arab waterway area near motor- boats and vessels $(\mathrm{N}=50)$. Samples were transported in cool boxes to the laboratory and stored at $20^{\circ} \mathrm{C}$ until they were processed. Five grams of soil (collected from the surface to a depth of about $5 \mathrm{~cm}$ with sterile spatulas) were dissolved in $45 \mathrm{ml}$ sterile normal saline in a sterile flask (Margesin et al., 2013), serially diluted then cultured. Five liters of Municipal water samples were filtered through sterile Millipore filters apparatus (Pore size $=0.45 \mu$ ). Swabs taken from filter papers were cultured. Samples of surface water polluted with diesel oil were collected in screw-capped bottles and standard loopfuls were cultured.

The above samples were cultured on Leed Acinetobacter Medium (Jawad et al., 1994). It consisted of Casein hydrolysate (15gm), peptone ( $5 \mathrm{~g})$, mannitol ( $5 \mathrm{~g})$, sucrose $(5 \mathrm{~g})$, fructose $(5 \mathrm{~g}), \mathrm{NaCl}(5 \mathrm{~g})$, ferric ammonium citrate $(0.04 \mathrm{~g})$, phenylalanine $(2 \mathrm{~g})$, agar $(15 \mathrm{~g})$, phenol red $(0.02 \mathrm{~g})$ dissolved in distilled water (1litre) by heating and $\mathrm{pH}$ was adjusted to 6.8 . The medium was sterilized by autoclave, cooled to $50-55^{\circ} \mathrm{C}$ then $10 \mathrm{mg}$ of the antibiotic vancomycin was added before pouring into sterile Petri dishes. Cultured plates were incubated at $30^{\circ} \mathrm{C}$ for $24-48 \mathrm{hrs}$. Entire, smooth, convex and pink colonies of 1-2 mm diameter giving up to Gram-negative diplococcal bacilli were selected. The above colonies were identified to belong to the genus Acinetobacter for their ability to produce catalase, oxidase, gelatinase, oxidation/fermentation test, growth in tryptic soy broth after incubation in a water bath at the following temperatures: 37 , 41 and $44^{\circ} \mathrm{C}$ (Bouvet and Grimont, 1987). To identify isolates of recovered Acinetobacter to the species level, utilization of $0.01 \mathrm{~g}$ $100 \mathrm{ml}^{-1}$ of the following carbon sources: L-alanine, sodium citrate, sodium butyrate, L-Histidine, and sodium malonate was carried out (Veron, 1975). Degradation of PAH resulting due to the growth and activity of bacteria was followed spectrophotometrically (Pavia et al., 2001) in the range 200-800 $\mathrm{nm}$. Also, degradation was followed gravimetrically by measuring weight loss through weighing PAH after complete drying from the solvent (Harris, 2010).

The activity of isolated bacteria on polycyclic aromatic hydrocarbon (PAH): The mineral medium was prepared according to Fujisawa et al. (1977). It consists of: $\mathrm{NH}_{4} \mathrm{Cl}(0.5 \mathrm{~g})$; $\mathrm{NaCl}(0.5 \mathrm{~g}) ; \mathrm{Na}_{2} \mathrm{HPO}_{4}(1 \mathrm{~g})$ and $\mathrm{KH}_{2} \mathrm{PO}_{4}(1 \mathrm{~g})$ dissolved in $1 \mathrm{I}$ distilled water; $\mathrm{pH}$ was adjusted to 7.5 then autoclaved. $\mathrm{PAH}$ $(0.1 \mathrm{~g})$ was dissolved in $1 \mathrm{ml}$ chloroform then added to $(250 \mathrm{ml}$ ) mineral medium. 
Cultures $\left(1 \mathrm{ml}\right.$ of $10^{8}$ bacteria $\left.\mathrm{ml}^{-1}\right)$ of each identified Acinetobacter species were added to aliquots $(250 \mathrm{ml})$ mineral medium in flasks containing dissolved PAH. Replicate flasks for each species were prepared and incubated at $30^{\circ} \mathrm{C}$ for two months. Measurements were made along this incubation period, at three interval times: After two weeks; four weeks and after eight weeks of incubation. Measurements included examination of changes in $\mathrm{pH}$ (using the $\mathrm{pH}$ meter) and growth of bacteria (direct counting of bacterial cells) using Petroff-Hausser chamber as described by Wistreich and Lechman, (1980). Degradation of PAH resulted due to the growth and activity of bacteria was tracked spectro photometrically (Pavia et al., 2001) in the range 200-800 nm. Also, weight loss of PAH was followed gravimetrically through weighing PAH after complete drying from the solvent (Harris, 2010). After each incubation period with bacteria, the remaining PAH was extracted using a separating funnel. Five $\mathrm{ml}$ of chloroform was added, the funnel was shaken for 15-20 min. Extraction was completed after $24 \mathrm{hr}$. The precipitate was separated from chloroform in sterile test tubes then dried after being put in sterile Petri dishes and left until complete evaporation of the solvent was achieved.

Statistical analysis: Analysis of variance (ANOVA test) using Statistical Package for Social Sciences (SPSS) was adopted.

\section{Results and Discussion}

Agar plates of LAM changed from brown to red owing to the growth of Acinetobacter. Out of one hundred and five samples, ten isolates of Acinetobacter were obtained (9.53\%). The largest percentage recovery (16\%) was from soil polluted with diesel oil. Following characterization of recovered Acinetobacter isolates two species were identified, $A$. I woffii and A. calcoaceticus. According to differentiation tests, it was found that apart from sodium butyrate, $A$. calcoaceticus was able to utilize L-Histidine, citrate, $\beta$ - alanine and malonate as carbon sources. The incidence of recovered $A$. Iwoffii and $A$. calcoaceticus was $8(8 \%)$ and $2(2 \%)$, respectively. A. Iwoffii was isolated from three sources under study with the highest percentage recovery from soil polluted with diesel oil ( $N=6,12 \%)$ followed by Municipal drinking water $(\mathrm{N}=1,5 \%)$, while the least percentage was obtained from surface water polluted with diesel oil $(\mathrm{N}=1,2.85 \%)$. A. calcoaceticus was isolated only from soil polluted with diesel oil $(\mathrm{N}=2,4 \%)$. The microbial analysis shows that along with the incubation period, the bacterial population of two species of Acinetobacter started to increase at the beginning of the experiment reaching up to $\left(10^{11}\right)$ bacterial cell $\mathrm{ml}^{-1}$ by the end of first two weeks, but the number dropped to $\left(10^{5}\right)$ bacterial cell $\mathrm{ml}^{-1}$ after four weeks. The bacterial population continued to decline to reach down to $\left(10^{2}\right)$ bacterial cell $\mathrm{ml}^{-1}$ after eight weeks when the experiment was terminated. This reduction in bacterial population was concomitant with the decrease in the weight of PAH (Table 1). According to Lambert-Beer's law, the UV- visible absorption can be related to the concentration of the absorbing species or compound, for a given compound a higher absorption than another absorption indicates that a higher concentration of the former than the latter (Pavia et al., 2001). The UV-visible absorption spectrum of PAH in sterile mineral medium $(\mathrm{pH} 7)$, before the addition of the studied bacteria, showed two absorption bands. The highest intensity band was at maximum wavelength of $350 \mathrm{~nm}$ and the lowest intensity band at maximum wavelength of $450 \mathrm{~nm}$. The effect of incubating two bacterium species with PAH was achieved separately, and the spectrum was monitored after two weeks, four weeks and eight weeks. A consistent result from the spectra revealed a decrease in the intensity, absorbance, at the given wavelengths as the time elapsed. The decrease in the intensity agrees with the observed decrease of PAH weight which were in contact with bacteria as the time advanced, both indicates a decrease in PAH concentration.

Bioremediation is the degradation of organic contaminants in soil or water, by the action of cultured microorganisms selected for their ability to metabolize specific pollutants notably petroleum hydrocarbons (Chang et al., 2011). Microorganisms break down pollutants by using them as energy source or co-metabolizing them with energy source. These reactions include respiration and other biological functions needed for cell maintenance and reproduction (Adams et al., 2015). The presence of microorganisms with appropriate metabolic capabilities is an essential requirement for oil spill bioremediation (Röling et al., 2002). Exposed microbial communities to hydrocarbons become adapted and exhibit selective enrichment and genetic changes, therefore, they can respond to the presence of hydrocarbon pollutants within hours and exhibit higher biodegradation rates than communities with no history of hydrocarbon contamination (Atlas and Bartha, 1998). This finding might explain the increase in the number of Acinetobacter (oil degrading) in the present study. Nevertheless, Couling et al. (2010) reported that widespread capacity of microbial communities degrade PAH even from unpolluted soils because PAH are ubiquitously distributed in the environment at low concentrations, sufficient for bacteria to develop degrading capacity.

Although, a large number of degrading bacteria from contaminated soils have been identified including Bacillus, Proteus, Pseudomonas, Flavobacterium, Corynebacterium, Serratia, Micrococcus, Klebsiella, Enterobacter and Azotobacter. (Das and Chandran, 2011, Chikere, 2012; Xu, 2012); temperature plays a significant role in controlling the nature and the extent of microbial hydrocarbon metabolism (Margesin, 2013). The temperature of the surrounding water determines the rate of hydrocarbon degradation. Zaki et al. (2015) reported that crude oil degradation is faster in warm water because the heat generated within the water body will further encourage the breakdown of the spilled petroleum through natural processes such as evaporation. Besides, Fatajeva et al. (2014) reported that 
Table 1 : Changes in bacterial counts and weight of polycyclic aromatic hydrocarbon following the growth of Acinetobacter calcoaceticus and Acinetobacter Iwoffii for indicated incubation periods

\begin{tabular}{|c|c|c|c|c|}
\hline \multirow[t]{2}{*}{ Acinetobacter spp. } & \multicolumn{4}{|c|}{ Incubation periods } \\
\hline & 0 Time & After 2 weeks & After 4 weeks & After 8 weeks \\
\hline \multicolumn{5}{|l|}{ A. calcoaceticus } \\
\hline Bact. cell $\mathrm{ml}^{-1}$ & $5 \times 10^{8}$ & $8.05 \times 10^{11}$ & $6.3 \times 10^{5}$ & $0.2 \times 10^{2}$ \\
\hline Wt. PAH(g 250m-1 $)$ & 0.1 & 0.053 & 0.013 & 0.001 \\
\hline \multicolumn{5}{|l|}{ A. Iwoffii } \\
\hline Bact. cell ml ${ }^{-1}$ & $5 \times 10^{8}$ & $1.23 \times 10^{11}$ & $6.25 \times 10^{5}$ & $0.6 \times 10^{2}$ \\
\hline Wt. PAH (g 250ml' $\left.{ }^{-1}\right)$ & 0.1 & 0.031 & 0.009 & 0.003 \\
\hline
\end{tabular}

Acinetobacter is the most active bacteria to degrade crude oil and fuel oil at a temperature of $30^{\circ} \mathrm{C}$, in a pH range of 7-8, in model ocean water of $35 \%$ salinity. The above studies run parallel with the results of the present study where both species of Acinetobacter recovered from diesel polluted soil and water of tropical area, as in Shatt Al-Arab waterway, where the ambient temperature is higher than $30^{\circ} \mathrm{C}$ throughout the year. Using a liquid phase culture systems to increase the bioavailability of substrates for uptake and biodegradation (Lafortune et al., 2009), the two recovered species of Acinetobacter behaved approximately in a similar way. As a result of utilization of PAH, bacterial population of the two species of Acinetobacter, increased during the first two weeks of the experiment and their number dropped continually after two months with the decrease in the weight of PAH. Starting with $5 \times 10^{8}$ bacterial cell $\mathrm{ml}^{-1}$ of the species $A$. calocoacetcus; the count was increased to $8.05 \times 10^{11}$ cell $\mathrm{ml}^{-1}$ after two weeks then decreased to $6.3 \times 10^{5}$ cell $\mathrm{ml}^{-1}$ after one month and became $0.2 \times 10^{2}$ bacterial cell $\mathrm{ml}^{-1}$ after two months. Accordingly, the weight of PAHs was decreased from 0.1

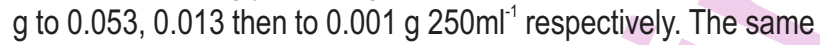
sequence of events was demonstrated by $A$. Iwoffii, but with a higher rate of degrading confirming its higher potency for bioremediation (Table 1), however, with no significant difference. Also, a decrease in the absorbance of UV-visible spectrum of PAH incubated separately with each species of Acinetobacter gives another evidence of degradation of $\mathrm{PAH}$ by the two studied species; this indicates that degradation of PAH occurred as bacteria uses it as carbon source and energy. It is worthwhile to mention that oil-degrading Acinetobacter produces an extracellular polyanionic, heteropolysaccharide bioemulsifier termed emulsan consisting of high-molecular-mass polysaccharides associated with proteins which also stabilizes oil-water and water-oil emulsions (Toren et al., 2001; Margesin et al., 2013; Fatajeva et al., 2014 ). The study also revealed that using mineral medium without addition of nutrients was adequate for enhancing bacterial growth and degradation activity of both species of Acinetobacter. Nevertheless, Adams et al. (2015) reported that where the indigenous identifiable petroleum degrader was too small, introduction of trace nutrients for microbial growth would be necessary which also serves as an electron donor, to stimulate bioremediation.
In this study, it is concluded that bioremediation by two species of Acinetobacter is achievable using a mineral medium. It is a promising alternative to clean oil spills to reduce the concentration and toxicity of pollutants. The two Acinetobacter spp. have approximately similar degradable effects.

\section{References}

Adams, G.O., P.T. Fufeyin, S.E. Okoro and I. Ehinomen: Bioremediation, biostimulation and bioaugmention: A Review. Int. J. Environ. Biorem. Biodeg., 3, 28-39 (2015).

Agency for Toxic Substances and Disease Registry (ATSDR): Case studies in environmental medicine toxicity of polycyclic aromatic hydrocarbons (PAHs), pp.1-68 (2012).

Atlas, R.M. and R. Bartha: Quantitative ecology: numbers, biomass, and activities. In.: Microbial Ecology: Fundamentals and Applications (Eds.: R.M. Atlas and R. Bartha) $4^{\text {th }}$ edn., Benjamin / Cummings, pp. 694 (1998)

Barathi, S. and N. Vasudevan: Utilization of petroleum hydrocarbons by Pseudomonas fluorescence isolated from petroleum contaminated soil. Environ. Int., 26, 413-416 (2001).

Bouvet, P.J.M. and P.A.D. Grimont: Identification and biotyping of clinical isolated of Acinetobacter. Am. Microbiol. Inst. Pasteur, 138, 569578 (1987).

Brooijmans, R.J.W., M.I. Pastink and R.J. Siezen: Hydrocarbondegrading bacteria: The oil-spill clean-up crew. Microb. Biotechnol., 2, 587-594 (2009).

Chang, K.L., D. Ibrahim and C.O. Ibrahim: A laboratory scale bioremediation of Tapis crude oil is contaminated soil by bioaugmentation of Acinetobacter baumannii T30C. Afri. J. Microbiol. Res., 5, 2609-2615(2011).

Chikere, C.B.: Culture-independent analysis of bacterial community composition during bioremediation of crude oil-polluted soil. Brit. Microbiol. Res. J., 2, 187-211 (2012).

Couling, N.R., I.M.G. Towe and K.T. Semple: Biodegradation of PAH in soil: Influence of chemical structure, concentration, and multiple amendments. Environ. Pollut., 158, 3411-3420 (2010).

Das, N. and P. Chandran: Microbial degradation of petroleum hydrocarbon contaminants: An Overview. Biotechnol. Res. Int., Vol. 2011, 13 pages, doi : 10.4061/2011/941810 (2011).

Dubinsky, E.A., M.E. Conrad, R. Chakraborty, M. Bill, S.E. Borglin, J.T. Hollibaugh, O.U.M. Mason, Y. Piceno, F.C. Reid, W.T. Stringfellow, L.M. Tom, T.C. Hazen and G.L. Andersen: A succession of hydrocarbon-degrading bacteria in the aftermath of the deepwater horizon oil spill in the gulf of Mexico. Environ. Sci. Technol., 47, 
10860-10867 (2013).

Fatajeva, E., I. Gailiūtè, D. Paliulis and S. Grigiškis: The use of Acinetobacter spp. for oil hydrocarbon degradation in saline waters. Biologija, 60, 126-133 (2014).

Fujisawa, H., M. Murakami and T. Manabe: Ecological studies on hydrocarbon oxidizing bacteria in Japanese coastal water, 1:some methods of enumeration of hydrocarbon oxidizing bacteria. Bull. Jap. Soci. Sci. Fisheries, 43, 659-668 (1977)

Harris, D.C.: Quantitative Chemical Analysis. $8^{\text {th }}$ Edn., Publisher: W. H. Freeman and Company, New York (2010).

Haritash, A.K. and C.P. Kaushik: Biodegradation aspects of polycyclic aromatic hydrocarbons (PAH): A review. J. Hazard. Mater., 169, $1-15(2009)$.

Jawad, A., P.M. Hawkey, J. Heritage and A.M. Snelling: Description of Leeds Acinetobacter medium, a new selective and differential medium for isolation of clinically important $A$ cinetobacter spp. and comparison with Herellea agar and Holton's agar. J. Clin. Microbiol., 32, 2353-2358 (1994).

Kingston, P.F.: Long-term environmental impact of oil spills. Spill Sci. Tech. Bull., 7, 53-61 (2002).

Lafortune, I., P. Juteau, E. Déziel, F. Lépine, R. Beaudet and R. Villemur: Bacterial diversity of a consortium degrading high-molecularweight polycyclic aromatic hydrocarbons in a two-liquid phase biosystem. Microb. Ecol., 57, 455-68 (2009).

McMahon, A.M., E.M. Doyle, S. Brooks and K.E. O'Connor: Biochemical characterization of the coexisting tyrosinase and laccase in the soil bacterium Pseudomonas putidaF6. Enzyme Microb. Technol., 40, 1435-1441 (2007).

MacNaughton, S.J., J.R. Stephen, A.D. Venosa, G.A. Davis, Y.J. Chang and D.C. White: Microbial population changes during bioremediation of an experimental oil spill. Appl. Environ. Microbiol., 65, 3566-3574 (1999).

Margesin, R., C. Moertelmaier and J. Mair: Low-temperature biodegradation of petroleum hydrocarbons ( $n$-alkanes, phenol, anthracene, pyrene) by four actinobacterial strains. Int. Biodeterior. Biodegrad., 84, 185-191 (2013).

Mason, O.U., J. Han, T. Woyke and J.K. Jansson: Single cell genomics reveals features of Colwellia species that was dominant during the deep-water horizon oil spill. Frontiers Microbiol. Aqu. Microbiol., 5, 29-36(2014)

Mohandass, R., P. Rout, S. Jiwal and C. Sasikala: Biodegradation of benzo[a]pyrene by the mixed culture of Bacillus cereus and Bacillus vireti isolated from the petrochemical industry. J. Environ. Biol., 33, 985-989 (2012).

Pavia, D.L., G.M. Lampman and G.S. Kriz: Introduction to Spectroscopy. 3rd Edn., Thomson Learning Academic Resource Center, USA, (2001).

Röling, W.F., M.G. Milner, D.M. Jones, K. Lee, F. Daniel, R.J. Swannell, and I.M. Head: Robust hydrocarbon degradation and dynamics of bacterial communities during nutrient-enhanced oil spill bioremediation. App. Environ. Microbiol., 68, 5537-5548(2002).

Skupinska, K., I. Misiewicz and T. Kasprzycka-Guttman: Polycyclic aromatic hydrocarbons: Physico-chemical properties, environmental appearance and impact on living organisms. Acta Pol. Pharm., 61, 233-40 (2004).

Taketani, R.G., N.O. Franco, A.S. Rosado and J.D. van Elsas: Microbial community response to a simulated hydrocarbon spill in mangrove sediments. J. Microbiol., 48, 7-15 (2010).

Toren, A., S. Navon-Venezia, E.Z. Ron and E. Rosenberg: Emulsifying activities of purified alasan proteins from Acinetobacter radioresistens KA53.Appl. Environ. Microbiol., 67, 1102-1106(2001).

Veron, M.: Nutrition et taxonomie des Enterobacteriaceae et bactéries voisines. 1. Methode d'etude des auxanogrammes. Ann. Microbiol. Paris, 126A, 267-274 (1975).

Wistreich, G.A. and M.D. Lechman: Microbiology. $3^{\text {rd }}$ Edn., Collier Macmillan, London, p. 267 (1980).

$\mathrm{Xu}, \mathrm{J}$.: Bioremediation of crude oil contaminated soil by petroleumdegrading active bacteria. In: Introduction to Enhanced Oil Recovery (EOR) Processes and Bioremediation of OilContaminated Sites (Ed.: Laura Romero-Zerón). INTECH Open Access Publisher (2012).

Zaki, M.S, M.N. Authman and H.H. Abbas: Bioremediation of petroleum contaminants in aquatic environments (Review Article). Life Sci. J., $12,127-139(2015)$ 